\title{
Social Conflicts Between Oil-Palm Plantation Company and Indigenous People in Jambi Province
}

\author{
Dewi Nilakrisna ${ }^{1}$, Ridha Taqwa ${ }^{2}$, Sriati ${ }^{3}$, Dadang H Purnama ${ }^{2}$, Robiyanto H Susanto ${ }^{2}$
}

${ }^{1}$ Environmental Sciences Program, Sriwijaya University, Palembang, Indonesia

${ }^{2}$ Faculty of Social and Politic Sciences, Sriwijaya University, Palembang, Indonesia

${ }^{3}$ Faculty of Agriculture, Sriwijaya University, Palembang, Indonesia

\section{ABSTRACT}

The oil-palm plantation development policy meant to increase the economic growth and to provide jobs opportunities in rural area. The development policy that participate the private sectors creates many social conflict in Indonesia, especially against the indigenous people community. The purpose of this research is to find out, how the oil-palm plantation development policies implemented and the impact to the indigenous people community in Batanghari Regency, Jambi Province. This qualitative research used case study approach and qualitative data analysis based on extended text. Obtaining data through direct observation, in-depth interview, structured interview, and literature studies.

The study results showed that the implementation of the large scale oil-palm plantation development policy, has caused approximately $1 / 3$ area of Batang Hari Regency was controlled by the private companies and give negative impacts to almost 3.000 peoples of SAD Batin 9 community. They have been evicted, marginalized and face the uncertainty rights to the land. The implementation of oil-palm plantation development policy without take a notice to the existing social environmental condition has deny the indigenous people existence. It has stimulated some contradiction to the injustice government policy. Therefore this research recommends the government to consider about the social and environmental impacts before issued any policy in order to protect the social justice for all citizens.

Keywords: Policy, social conflicts, natural resources, indigenous people, corporation

\section{INTRODUCTION}

Public policy is often comprehended as an instrument used by the government to solve public problems. The Government chose the best alternative to settle the problem [1]. Dunn was describe that public policy is something to be done or not to be done by the government [2]. The government choice is largely determine the fate of society as the policy object.

Natural resource management policy in Indonesia that adopt the paradigm of growth has caused many exploitations to natural resources (such programs in forestry, plantations, fisheries and mining sectors) in various region of Indonesia [3]. Batanghari Regency in Jambi Province is one of the regions with high forest coverage area that reached $90 \%$ at the beginning of the

\section{${ }^{*}$ Corresponding author:}

Dewi Nilakrisna

Environmental Sciences Program, Sriwijaya University

Jalan Palembang - Prabumulih Raya KM 32-UNSRI Inderalaya,

Ogan Ilir, Palembang 30662, Indonesia

E-mail: dwnk97@gmail.com decade of the 70s. However nowadays the distribution of land coverage dominated by plantation (31.66\%) due to permit issued managed by companies both private and state-owned enterprises [4].

Under the constitution UUD 1945 Article 33 that earth, water, air, and natural resources contained therein shall be controlled by the state and used optimally for the prosperity of the people. According to the article, the state is the only institution that has the right to establish and revoke land rights in Indonesia [5]. The article became the basis for the state to control the natural resources and the implementation is stipulated in Basic Agrarian Law (No. 5/1960), Forestry Law (No. 41/1999) and various regulations Law. The Goverment of Indonesia begun to built the oil-palm planta-

\section{How to cite:}

Nilakrisna D, Taqwa R, Sriati, et al. (2016) Impact of private oil-palm plantation development policy to indigenous people's life in Jambi province. J. Trop. Life Science 6 (2): 111 - 117. 
tions since the beginning of the 80's decade. As representatives of the state, government handing out forest land to investors for development of oil-palm plantations through leasehold schemes (HGU).

The policy of development oil-palm plantations in the region of Batanghari causes social conflicts. A group of indigenous people who identified themselves as Anak Dalam Batin 9 Sungai Beruang (here in after referred to as SAD Batin 9 Sungai Beruang), trying to oppose the presence of oil-palm plantation companies. They vowed that it established on the land of their ancestors that they have extracted since hundreds of years ago. Even they have stated their position clearly, but they are always in a weak position. They had been eliminated from their ancestral lands and lived in poverty, intimidation and uncertainty of tenure. Resistance over the last 30 years shows that the policy of government intervention does not produce a resolution in favor SAD Batin 9 community.

\section{MATERIALS AND METHODS}

The purpose of this research is to find out, how the oil-palm plantation development policies implemented and it's impact to the indigenous people in Batanghari Regency Jambi Province. The qualitative research with case study approach obtains data through direct observation, in-depth interview, structured interview and literature studies. Primary data had been collected by direct observation and in-depth interview with the related stake holders such as local governments, private company, NGO, and the indigenous community. Secondary data was taken from the available existing books, reports, maps, regulation, etc.

Research informants obtained through purposive technique in the early stages followed by a snowball technique to produce some relevant saturated data. The data analysis was done by using qualitative descriptive technique based on extended text. The data got from the interviews and the observations was written in a detailed field reports, then it were analyzed descriptively by a systematic procedures such as the data reduction (generalizing, abstracting and transforming the raw data derived from the field reports), the data presentation (the information arrangements to get conclusion), conclusion formulation based on the reduction, and repeatable and cyclical data presentation.

\section{RESULTS AND DISCUSSION}

According to Article 28 and 29 paragraph, 1 of UUPA, cultivation right (HGU) is the right to cultivate land directly controlled by the State. So HGU can not be granted on land that does not state land status. In the reality, the given land concession cover a large part of the customary land rights of indigenous people. The state land normally only found in forest areas. Therefore, the government must do two actions, which are releasing of indigenous communal land or changing the status of forest to be the HGU [5].

The PTPN VI develop oil-palm plantations in Batanghari Regency at the early 80s with a PIR Trans schame. Next, Senangsyah family invested on oil-palm plantations by established BDU [5]. The company gets the license on 20 April 1985 and Backup Land Permits on December 3, 1985, from The Government of Jambi Province to an area of 40,000 hectares in the work area of HPH A and TA company. The government of Jambi Province applied the exchange of forest areas to the Minister of Forestry on December 2, 1985, by designating forest areas in the district of Kumpeh as a substitute area. On December 6, 1985, BDU company also applied a conversion permit for limited production forest into plantations (APL) to the Forestry Ministerial.

The Ministerial of Forestry through the Agency for Inventory and Land Use Issued Letter No. 393/VII4/1987 concerning notification of the approval of the release of forest land to BDU company. The letter explained that, based on micro survey results, from 30,000 hectares proposed, only 27.150 hectares of land that can be released. It hasbeen composed of 23,600 hectares are forest, 1,400 hectares are coppice, 2,100 hectares are cultivated land and 50 hectares of residential areas. The Minister of Forestry Decree was officially released on July 3, 1992, through Decree $667 /$ Kpts-II/1992 with the area of 2,650 hectares.

On January 20, 1986, BDU company apply for concession certificates of 20,000 hectares (the maximum limit of a leasehold). Minister of Home Affairs published SK.46/HGU/ BA/86, and BPN of Batanghari issued HGU No. 1 of 1987 on 20 May 1987. This concession certificate gives the land right to BDU company for 35 years. The rights will expire on 20 May 2021. The map of forest area Extrication and the map of corporation's HGU can be seen on Figure 1 and Figure 2 .

In administrative process to obtain HGU of BDU company, founded several irregularities that indicate maladministration practices, lack of coordination among government agencies, corruption controlling. Forest Minister on the release of forest land recently issued after five years from approval notification letter issued. The corporation should not start the working before the official decree rumored by the Ministry of Fo- 


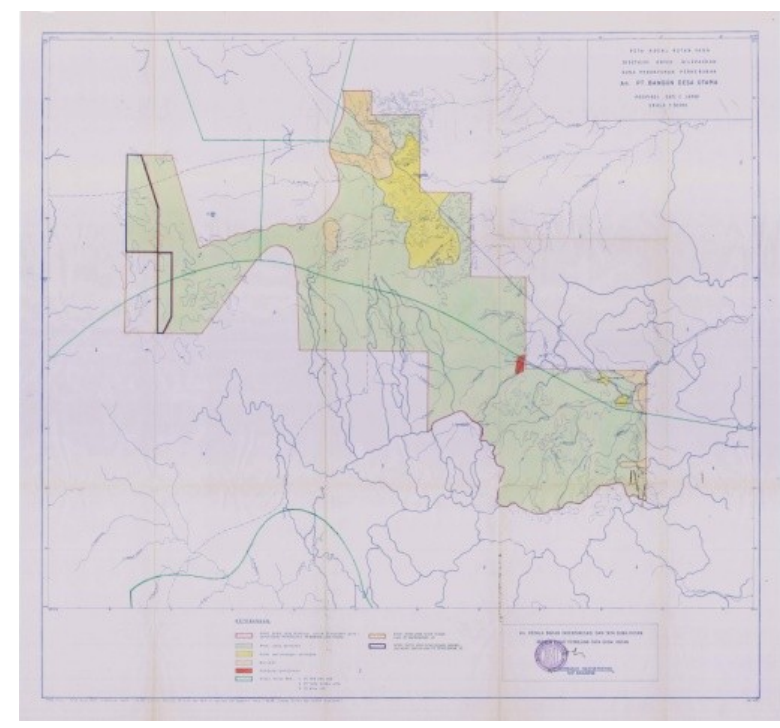

Figure 1. Map of forestry area extrication for BDU company

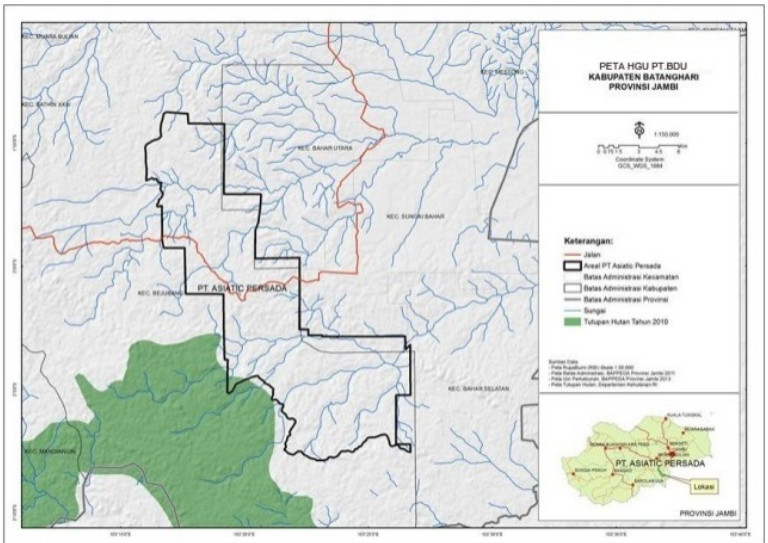

Figure 2. Map of BDU company 's HGU in SAD Batin 9 livelihood

restry. However, the fact, the corporation started its activities since they have the concession decree of the Minister of the Home Affairs and HGU Certificate from Batanghari Regency's BPN.

Supposedly HGU decree and Certificates of BDU company canceled by the law, because the HGU Decree and Certificate (1987) preceded the Forest Areas Extrication decree (1992). BKPMD Jambi Province decree mentioning that the maintenance of the concession held after the completion of the release of the forest area is done. Likewise, the Forest Areas Extrication decree has mandating the BPN to issue certificates of HGU after Forest Areas Extrication decree issued. In reality, the certificate of HGU was published in 1987, which indicated that there is a manipulation in the process of licensing the BDU company. The issuance of HGU Decree and HGU Certificate that released before Forest Areas Extrication Decree is the result of lack coordination among government agencies, Ministry of Home Affairs, BPN and Forestry Department. The Ministry of Home Affair and BPN are the authorized agencies who issues the HGU decree and the certificate. The Forestry Departement the authorized agency who issues the Forest Area Extrication Decree.

After the issuance of the decree and the concession certificate in 1987, BDU company started their operation in the northern part of the concession area. The first clash they face is the existence of the village, the fields and gardens of indigenous people SAD Batin 9 in several locations within the concession area. Concession area was not an empty land without inhabitants and ownership. According to the SAD Batin 9 who live in the northern part of the concession (Tanah Menang, Padang Salak, and Pinang Tinggi sub-villages) the corporation promised to plant cocoa without disrupting plant of SAD Batin 9. However, then the cocoa farm exhausted, and then planted with oil-palm. The rubber trees and fruit trees belong to the people who have lived for decades were terminated. BDU company was also displacing six old cemeteries belonging to the community. The police and the army helped the corporation to expel SAD Batin 9 community. Hundreds of families SAD Batin 9 lost their homes and livelihoods $[5,6]$

People of SAD Batin 9 who live in the southern part of the concession, namely Sungai Beruang Sub Village in 2011, experience ecictions and expulsions. At that time, the company management has been transferred to AP company. Companies use heavy equipment such as bulldozers and excavators for SAD Batin 9 settlement ravaging at 3 locations (Sungai Buaiyan, Danau Minang, and Jembatan Besi). For people who persist, they were forced removed by police and soldiers assigned to evict the remaining $[7,8]$.

The eviction and the expulsion of SAD Batin 9 community conducted by AP company citing the existence of the SAD Batin 9 in the concession area actually had been unlawful. The Company is the holder of the rights to the area because the government has given permission. It does not mean that Indigenous people could consider as squatters who disrupt the company plantation. The criminalization of indigenouspeople is one way to get rid of them from the area of the concession. From the perspective of indigenous people SAD Batin 9, the action was taken by the company is the deprivation of the right to the living area, because they have live and make a living in this area since hundreds of years ago. They obtained the land of their ancestors. They also buried their ancestors in the 
same land. The corporation come and seize their land. Just because they do not have land certificates, does not mean they are criminals. They are Indonesian citizens as well. They have the same rights to life without stress, intimidation or deprivation of property rights.

In the other sight, the action of the BDU company/ AP company displacing people SAD Batin 9 in the area of the concession is unlawful. In the Principle Permit of the SK released of Forest Areas and the Micro Maps Survey, HGU decree has been mandated to release the villages, fields and thickets indicated agricultural activity and existing plantations. The map of micro survey discovered 1,400 hectares of bushland, 2,100 hectares of fields and 50 hectares of settlement. The company is obliged to give the compensation in a way by regulatory requirements. Violent actions that violate human rights committed by the company against SAD Batin 9 community should get legal sanctions. However the fact the government has not been able to do much. Although the Jambi Provincial government has been trying to mediate negotiations between the two way out of justice is still far from expectations. The other actions done by the government is just incidental as providing material assistance to the victims of eviction. The need of SAD Batin 9 community is the completion of a broad problem that touches the root causes. A policy that could help them out of poverty and safeguard they dignity.

Hundreds of SAD Batin 9 families who were displaced from their villages in the northern part of the concession, identify their group as SAD 113. 83 families displaced in the southern one is the Sungai Beruang sub-village community. There are still many groups of SAD Batin 9 is striking against the existence of private oil-palm plantation on the land of their ancestors. There are at least seven groups with different demands and issues that do struggle to claim their rights over the land held by the company. They do many demonstrations to various government agencies both regional and national level, to draw the attention of all parties to care about their fate.

Assistance from various NGOs (CAPPA, SETARA, AGRA, Sawit Watch, Green Society, etc.) is very helpful in implementing SAD Batin 9 protest action. NGOs and SAD Batin 9 send many letters of complaints to various agencies. Some agencies at the national level such as the National Commission on Human Rights, Regional Representatives Council, District Representatives Council and BPN has come down to the location of the conflict. However, their attention has not been able to resolve the conflict. Letter of complaint from the SAD Batin 9 to the management of the company in Singapore which was forwarded to the RSPO and IFC about human rights violations and violence committed by AP company, get a positive response. The meeting between the conflicting parties held in January 2009 attttended by three groups of SAD Batin 9. Negotiations are underway within two years at the end did not get an agreement because the company only offers one solution that SAD Batin 9 should get out from the concession area and the company should give them any land outside of the concession. However, later the company unilaterally withdrew from the negotiations.

In 2011, an incident of eviction and expulsion occurred to the community of SAD Batin 9 in Sungai Beruang sub village. Alliance of NGOs and international NGOs submit a complaint to the CAO-IFC about human rights violations in Sungai Beruang subvillage. After the complaint, it was held a meeting with the parties in the conflict, local government, and CAO. Established the Joint Mediation Team (JOMET). Negotiations take place in four rounds. However, on 10, April 2013 negotiations stopped because AP company has changed the management to PT. AMS that has nothing concern with the IFC. So that the existence of the CAO-IFC is no longer relevant. He new management of corporation preferring Integrated Team of Batanghari Region consisting of the conflicting parties, the Region Government and Police of Batanghari to mediate negotiations. The final results of the Integrated Team are the distribution of 2,000 hectares of land outside the concession for the SAD Batin 9 [9].

Batanghari Regional Government and the Province of Jambi Government particularly have made various efforts to resolve the conflict. The Company had been called. The government asked the company to immediately settle the conflict with SAD Batin 9 but legal action for offenses was never held. Discourse in the first conflict resolution negotiation is giving the farm partnership for SAD Batin 9 at two locations within the concession area. It states in negotiation held in early February 2002. The government has conducted verification to SAD household entitled to receive the compensations. By the time, the substance of negotiations began to move. The company changed its policy withpartnership by offers 1,000 hectares outside the concession area. Then the Batanghari Regional Government issued Decree No. 244 of 2010 that only covers 771 households of SAD Batin 9 who would receives the partnership farm from AP company. It means not all SAD Batin 9 have been listed in the decree. Some groups are still demanding their rights. It enforced the 
company to give 1.000 hectares more [10].

The government considers the land conflict between the SAD Batin 9 and AP company has finished by the distribution of 2,000 hectares of land. However, the settlement is only capable of reducing open conflict. But the latent conflict will remain as the fundamental problem, namely, respect for people' rights of SAD Batin 9 on their ancestral lands. It is not accommodated by the government or the company. SAD Batin 9 receives farm partnership scheme with 2 hectares of land per household just because they have no choice. There is only one solution offered by companies, and local governments through the Integrated Team also recommends that people are receiving scheme. Social-economic conditions of the SAD Batin 9 is getting merely blue. They live in the semi-permanent home in the middle of oil-palm plantation company. They have to accept the only solution that offffered by the company. Deep inside, they miss the old life in their villages. Living with traditions blended with the surrounding nature. The farm partnership scheme can not guaranty a decent life for SAD Batin 9 because they will be tied to the company in the management and the crop sale. SAD Batin 9 as a partner can only accept the company's policy. It most rather like a new form of exploitation of indigenous.

\section{CONCLUSION}

The implementation of the high scale oil-palm plantation development policy has caused approximately $1 / 3$ region of Batanghari Regency land has been occupied by private companies. In the other hand it gives negative side effects to nearly 3.000 people of the SAD Batin 9 community. They have been evicted, marginalized and found uncertainty of their land rights. The implementation of oil-palm plantation development policy which ignored the negative externalizations has sideswiped the existence of the indigenous people community. This sparkled some contra movements to the socially injustice policy.

\section{ACKNOWLEDGMENT}

The authors would like to thanks the Environment
Science Doctoral Program of Sriwijaya University Graduate School for the research recomendation. The Government of Jambi Province for research funding. The Government of Batanghari \& Muaro Jambi Districts, PT. AMS, Setara Foundation, SAD Batin 9 Community and all those who contributed to the research.

\section{REFERENCES}

1. Indiahono D (2009) Kebijakan publik berbasis dynamic policy analysis, Yogya karta: Gava Media.

2. Dunn WN (1998) Pengantar analisis kebijakan publik: Indonesian Edition. Yogyakarta, Gadjah Mada University Press.

3. Kartodiharjo H, Jhamtani H [Editor] (2006) Politik lingkungan dan kekuasaan di Indonesia. Jakarta, Equinox.

4. Dinas Kehutanan Provinsi Jambi (2014) Statistik kehutanan Provinsi Jambi Tahun 2013). Jambi.

5. Afrizal (2007) Negara dan konflik agraria; Studi kasus pada komunitas pusat perkebunan kelapa sawit berskala besar di Sumatera Barat. Journal Universitas Airlangga 20 (3): $240-256$.

6. Hidayat R (2012) Membangkitkan Batang terendam: Sejarah asal usul, kebudayaan dan perjuangan SAD Batin 9 Jambi, Yayasan Setara.

7. Aziz A (2014) Sains sosial dan kajian pembangunan: Kumpulan rencana penghormatan untuk Profesor Abdul Rahman Embong - Pembangunan untuk siapa ? Dampak perkembangan industri perladangan kelapa sawit ke atas komuniti di Jambi, Indonesia. Malaysia, Vinlin Press Sdn Bhd.

8. Rofiq R, Hidayat R (2013) Mediasi; Strategi atau tujuan ? Sebuah catatan perjalanan dan mediasi konflik antara PT. Asiatic Persada dengan kelompok suku Anak Dalam Batin Sembilan di Jambi. Jambi, Setara.

9. Colchester M, Anderson P, Firdaus AY et al. (2011) Pelanggaran HAM dan konflik lahan di konsesi PT Asiatic Persada di Jambi. Laporan investigasi independen huma, sawit wacth, dan forest people programme. Indonesia.

10. Tim Terpadu Batanghari (2011) Laporan tim terpadu Batanghari tentang perkembangan penyelesaian konflik PT Asiatic Persada dengan masyarakat suku Anak Dalam. Muara Bulian. 